\title{
Bobot Produksi Telur Burung Puyuh (Coturnix-coturnix japonica) dengan Pemberian Larutan Daun Kelor
}

\author{
Maria Aditia Wahyuningrum, Bachtar Bakrie, dan Hendri Fahroji \\ Program Studi Agroteknologi Fakultas Pertanian Universitas Respati Indonesia Jakarta \\ Email: tia@urindo.ac.id
}

\begin{abstract}
ABSTRAK
Pemeliharaan burung puyuh (Coturnix-coturnix japonica) di daerah tropis tidak terlepas dari permasalahan konsumsi pakan dan cekaman stres akibat panas. Tanaman kelor menjadi salah satu alternatif pengganti antibiotic karena telah dikenal sebagai sumber nutrisi yang sangat baik dengan protein yang cukup tinggi dan baik bagi ternak monogastrik, dikenal pula sebagai sumber antioksidan alami yang mengandung karoteinoid, selenium, flavonoid dan fenolik yang dapat memperbaiki performa. Tujuan penelitian ini adalah mengetahui dan mengkaji tentang performa produksi telur burung puyuh (Coturnix coturnix Japonica) fase layer yang diberi larutan daun kelor (Moringa oleifera Lam) dalam air minum sebagai suplemen beta karoten yang aman dengan berbagai level dosis yang tepat. Penelitian menggunakan Rancangan Acak Lengkap (RAL) yang terdiri atas 4 perlakuan dan 5 ulangan pada masing-masing 5 ekor. Perlakuan air minum pada penelitian ini terdiri atas lima taraf pemberian yaitu : R1 = air minum tanpa larutan daun kelor (kontrol), R2 = larutan daun kelor 5\%, R3 = larutan daun kelor 10\%, dan R4 = larutan daun kelor $15 \%$. Variable penelitian meliputi bobot telur dan produksi telur. Analisis statistik dilakukan dengan menggunakan uji $F$ ANOVA, apabila hasil menunjukkan perlakuan berbeda nyata maka dilakukan uji perbandingan berganda duncan (Duncan's Multiple Range Test). Hasil perhitungan produksi telur burung puyuh pada R1 $=83,14-92,57 \%, \mathrm{R} 2=85,14-96,00 \%, \mathrm{R} 3=84,45-93,71 \%$ dan $\mathrm{R} 4=83,43-95,43 \%$ sedangkan bobot telur burung puyuh pada $\mathrm{R} 1=10,98-11,47 \mathrm{gram}, \mathrm{R} 2=$ $10,95-11,41$ gram, R3 = 11,11 - 11,50 gram, dan R4 = 11,17 - 11,70 gram.
\end{abstract}

Kata Kunci : Burung puyuh, Larutan kelor, Antioksidan alami, Bobot telur.

\begin{abstract}
Maintenance of quails (Coturnix-coturnix japonica) in the tropics is inseparable from the problem of feed consumption and stress stress due to heat. Moringa plants become an alternative to antibiotics because they have been known as an excellent source of nutrition with high enough protein and good for monogastric animals, also known as a source of natural antioxidants that contain caroteinoids, selenium, flavonoids and phenolics that can improve performance. The purpose of this study was to determine and study the performance of quail egg production (Coturnix coturnix Japonica) layer layer which was given Moringa oleifera Lam solution in drinking water as a safe beta carotene supplement with various appropriate dosage levels. The study used a completely randomized design (CRD) consisting of 4 treatments and 5 replications in each of 5 animals. The treatment of drinking water in this study consisted of five levels of administration, namely: R1 = drinking water without Moringa leaf solution (control), R2 = Moringa leaf solution $5 \%, \mathrm{R} 3=$ Moringa leaf solution $10 \%$, and R4 = Moringa leaf solution $15 \%$. Research variables include egg weight and egg production. Statistical analysis was performed using the ANOVA F test,

http://ejournal.urindo.ac.id/index.php/pertanian
\end{abstract}

Article History :

Sumbitted 09 Juni 2020, Accepted 29 Juni 2020, Published 30 Juni 2020 
if the results showed a significantly different treatment then a double comparative test was performed (Duncan's Multiple Range Test). The results of quail egg production calculations at R1 = $83.14-92.57 \%, \mathrm{R} 2=85.14-96.00 \%, \mathrm{R} 3=84.45-93.71 \%$ and $\mathrm{R} 4=83.43-95.43 \%$ while the weight of quail eggs at R1 = $10.98-11.47$ grams, R2 $=10.95-11.41$ grams, R3 $=11.11-11.50$ grams, and $\mathrm{R} 4=11.17-11.70$ grams .

Keywords : Quail, Moringa solution, Natural antioxidants, Egg weight.

\section{PENDAHULUAN}

Usaha peternakan tidak terlepas dari tahap pemilihan bibit, manajemen pemeliharaan perkandangan dan pakan. Selain itu, kesehatan ternak merupakan bagian dari usaha peningkatan produksi ternak, sehingga produktivitas ternakdapat dicapai secara optimal jika ternak yang dipelihara dalam keadaan sehat, pertambahan bobot badan memuaskan dan tingkat mortalitas rendah. Burung puyuh merupakan salah satu unggas yang harus dikembangkan dan ditingkatkan produksinya.Burung puyuh berproduksi cepat dan dalam waktu kurang lebih 41 hari mampu menghasilkan telur, dalam waktu setahun mampu menghasilkan 250-300 butir telur.

Telur puyuh mempunyai kandungan gizi yang tinggi karena telur puyuh mengandung $13,1 \%$ protein, lemak $11,1 \%$, karbohidrat $1 \%$ dan abu sebesar $1,1 \%$. Selain itu, harga daging dan telur puyuh relatif lebih murah jika dibandingkan dengan telur dan daging ayam atau bebek.Kondisi ini dapat membantu masyarakat yang kurang mampu untuk mengkonsumsi protein hewani.Namun salah satu permasalahan pemeliharaan ternak khususnya burung puyuh di daerah tropis adalah rendahnya konsumsi dan tingkat cekaman stress yang membuat performa produksi menjadi lebih rendah. Hal ini menyebabkan stressor utama yang mempengaruhi produksi unggas, respon perilaku dan kondisi fisiologis [1]. Naik turunnya suhu dan kelembaban menyebabkan produktivitas ternak menurun dan mortalitas meningkat. Bakteri yang biasa menyerang unggas adalah $S$ thypimurium dan $E$ coli. Pengobatan yang biasa dilakukan peternak adalah dengan menggunakan antibiotik. Penggunaan antibiotik yang tidak sesuai akan menyebabkan resistensi terhadap manusia yang mengkonsumi siternak tersebut. Sehingga perlu adanya alternatif pengganti antibiotik yang aman dan dapat digunakan untuk mengobati ternak yang mengalami stress dan terserang penyakit.

Tanaman kelor menjadi salah satu alternatif pengganti antibiotik karena telah dikenal sebagai sumber nutrisi yang sangat 
baik dengan protein yang cukup tinggi dan baik bagi ternak monogastrik, dikenal pula sebagai sumber antioksidan alami yang mengandung karoteinoid, selenium, flavonoid dan fenolik yang dapat memperbaiki performa. Oleh karena kemampuan zat -zat antioksidan untuk menjaga struktur makro molekul dasar biologis, zat yang secara nyata mampu menghambat oksidasi zat yang mudah teroksidasi serta menangkal radikal bebas oksigen reaktif jika berkaitan dengan penyakit [2]. Potensi larutan daun kelor (Moringa oleifera Lam) sebagai suplemen beta karoten untuk menghasilkan telur puyuh yang kaya anti oksidan. Tumbuhan kelor merupakan sumber berbagai jenis senyawa kimia yang berkhasiat obat yang salah satunya sebagai anti infeksi [3]. Tujuan penelitian ini adalah mengetahui dan mengkaji tentang performa produksi telur burung puyuh (Coturnix coturnix Japonica) fase layer yang diberi larutan daun kelor (Moringa oleifera Lam) dalam air minum sebagai suplemen beta karoten yang aman dengan berbagai level dosis yang tepat.

\section{METODE}

\section{Bahan dan Alat}

Bahan yang digunakan adalah ransum komersil BR-1 (pakan komplit tepung umur 1-21 hari) dan SP2 (pakan komplit tepung burung puyuh petelur diatas 5 minggu produksi PT Sinta Prima Feedmill, daunkelor,Formades, Zaldes,kapur gamping. Peralatan yang digunakan selama penelitian adalah kandang $60 \times 90 \times 15$. Kandang terbuat dari triplek dengan bagian alas kandang terbuat dari kawat ram agar kotoran puyuh dapat jatuh tidak menumpuk pada kandang. Setiap kandang dilengkapi dengan tempat pakan dan minum yang diletakkan di sebelah luar kandang. Setiap kandang dilengkapi dengan tempat pakan dan minum yang diletakkan di sebelah luar kandang. Selain itu, disediakan juga peralatan penunjang lainnya seperti lampu, papan penampung eskreta, ember, drum penampung air, panci, kompor, gayung, timbangan analitik 5000 gram, timbangan duduk, galon air, gelas ukur, meteran, sendok pengaduk, gelas ukur, kertas label, kantong plastik.

\section{Rancangan Penelitian}

Model rancangan yang digunakan pada penelitian ini adalah Rancangan Acak Lengkap (RAL) yang terdiri atas 4 perlakuan dan 5 ulangan pada masing-masing 5 ekor. Total pengamatan 100 ekor. Perlakuan air minum pada penelitian ini terdiri atas lima taraf pemberian yaitu : R1 = air minum tanpa larutan daun kelor (kontrol); R2= larutan daun kelor 5\%; R3= larutan daun kelor 10\%; R4= larutan daun kelor $15 \%$. 


\section{Cara Kerja}

\section{Persiapan Kandang}

Kandang dibersihkan dan dicuci dengan desinfektan berspektrum luas (Formades).Desinfektan tersebut adalah desinfektan dengan daya kerja kuat.Indikasi sebagai desinfektan dan anti septik. Setelah kandang bersih, maka kandang dan litternya ditaburi kapur / gamping. Kandang didiamkan (istirahat kandang) selama 2 minggu. Kemudian dicuci dan disemprot lagi dengan larutan desinfektan tersebut. Berikutnya jika sudah steril maka, kandang bias langsung digunakan.

\section{Persiapan Peralatan}

Peralatan disiapkan terlebih dahulu sebelum burung puyuh ada. Tempat pakan, tempat minum (galon minum $500 \mathrm{ml}$ ), papan penampung eskreta, ember, gayung, panci, timbangan analitik 5000 gram, termometer, meteran, sendok pengaduk, gelas ukur, kertas label dan kantong plastik, pisau, gunting, disemprot menggunakan Desinfektan (Zaldes). Desinfektan tersebut memberikan indikasi membunuh virus, bakteri dan jamur.

\section{Persiapan Ternak}

Ternak yang digunakan adalah 100 ekor burung puyuh fase starter umur 10 hari sampai fase bertelur 12 minggu. Burung puyuh ditempatkan sesuai rancangan acak lengkap. Burung puyuh dipelihara dalam kandang baterai selama penelitian. Sebelum memasuki tahap perlakuan, burung puyuh diadaptasikan dengan lingkungan penelitian. Adaptasi dilakukan selama 2 minggu dengan perlakuan yang akan diujikan.

\section{Pemberian Ransum}

Ransum yang akan digunakan pada penelitian ini adalah ransum BR-1 Crumble periode starter dan ransum komersil SP2 dari PT Sinta Prima Feed mill yaitu pakan komplit tepung burung puyuh petelur di atas 5 minggu. Pemberian ransum diberikan secara adlibitum. Jumlah konsumsi ransum 4 gram20 gram/ekor/hari. Pemberian pagi dimulai pukul 07.00 WIB.

\section{Pemberian Air Minum}

Air minum yang akan digunakan pada penelitian ini adalah air minum yang diberi perlakuan larutan daun kelor. Pemberian air minum dengan perlakuan diberikan secara adlibitu .Perlakuan dilakukan sampai selesai penelitian.

\section{Pemeliharaan Burung Puyuh}

Pemeliharaan ini dilakukan dari umur 10 hari hingga 21 hari. Pemeliharaan masa grower yaitu periode umur 3-6 minggu. Pemeliharaan masa layer yaitu saat burung puyuh berumur 6 minggu ke atas.

\section{Pengambilan Data}

Pengumpulan telur dilakukan $2 \mathrm{x}$ sehari pada pukul 09.00 WIB dan pukul 17.00 setelah pemberian pakan dan minum sore. http://ejournal.urindo.ac.id/index.php/pertanian 
Hal ini dimaksudkan supaya telur terkumpul semua. Telur yang dihasilkan dari masingmasing perlakuan dicatat jumlahnya.Telur dibersihkan dan diberi tanda sesuai perlakuan. Penimbangan telur dilakukan setiap hari setelah telur dikumpulkan. Untuk penghitungan konversi pakan (FCR) dan efisiensi produksi dilakukan seminggu sekali pada hari yang sama. Cara membuat ekstrak tepung daun kelor yaitu: (a) ambil beberapa cabang tanaman kelor, pilih daun segar berwarna hijau tanpa cacat dari tanaman yang berumur lebih dari 3 tahun, (b) daun kelor segar dan bersih, dipisahkan dari ranting dan tangkainya, serta diseleksi daun yang kuning, berbintik putih, masih muda atau rusak dipisahkan dan dibuang, (c) daun kelor segar dicuci untuk menghilangkan kotoran dan debu dan bagian tanaman, (d) daun kelor yang telah ditimbang kemudian diiris kecil, irisan tersebut direbus pada 100 $\mathrm{ml}$ air selama \pm 20 -30 menit dengan api kecil dan (e)rebusan daun kelor didinginkan dan disaring, kemudian hasil saringan daun kelor dicampurkan dengan air minum sesuai perlakuan [4].

\section{Variabel Pengamatan}

\section{Konsumsi ransum}

Konsumsi pakan (g) merupakan selisih dari jumlah pakan yang diberikan selama 1 minggu dengan jumlah sisa pakan [5].
Rumus konsumsi pakan (g/ekor) sebagai berikut :

= pakan pemberian $(\mathrm{g})-$ pakan sisa $(\mathrm{g})$

\section{Bobot telur}

Bobot telur didapat dari telur yang ditimbang menggunakan timbangan analisis.

\section{Produksi telur (\%)}

$=$ jumlah telur (butir) X100\% jumlah puyuh (ekor)

\section{Produksi massa telur}

Produksi massa telur merupakan hasil kali antara bobot telur dengan persentase produksi

$=$ Bobot telurX $\%$ Produksi telur

\section{Analisa Data}

Analisis statistik dilakukan dengan menggunakan uji $F$ ANOVA, apabila hasil menunjukkan perlakuan berbeda nyata maka dilakukan uji perbandingan berganda duncan (Duncan's Multiple Range Test).

\section{HASIL DAN PEMBAHASAN}

\subsection{Produksi Telur}

Produksi telur dipengaruhi oleh konsumsi dan faktor individu. Pakan yang dikonsumsi akan digunakan untuk hidup dan produksi telur. Produksi telur diperoleh dari jumlah telur yang dibagi dengan hasil perkalian antara jumlah ternak dengan jumlah telur setiap hari kemudian dikalikan 
seratus persen. Hasil penelitian yang diberi larutan daun kelor terhadap produksi telur

Tabel1. Produksi telur burung puyuh (\%)

\begin{tabular}{ccccc}
\hline Minggu & \multicolumn{4}{c}{ Perlakuan } \\
\cline { 2 - 5 } ke- & R1 & R2 & R3 & R4 \\
\hline 1 & $92,57 \pm 1,57$ & $96,00 \pm 2,55$ & $92,00 \pm 7,93$ & $95,43 \pm 4,78$ \\
2 & $90,29 \pm 6,26$ & $92,00 \pm 2,39$ & $93,71 \pm 7,92$ & $93,14 \pm 8,71$ \\
3 & $88,57 \pm 4,95$ & $93,71 \pm 7,93$ & $86,29 \pm 8,90$ & $88,00 \pm 12,19$ \\
4 & $88,00 \pm 7,79$ & $86,22 \pm 3,98$ & $87,56 \pm 4,87$ & $87,11 \pm 10,93$ \\
5 & $85,71 \pm 6,70$ & $91,43 \pm 8,33$ & $86,00 \pm 7,31$ & $83,43 \pm 8,42$ \\
6 & $85,86 \pm 7,63$ & $87,43 \pm 9,61$ & $89,00 \pm 10,44$ & $84,57 \pm 8,71$ \\
7 & $83,14 \pm 5,75$ & $85,14 \pm 4,69$ & $89,29 \pm 10,17$ & $83,43 \pm 8,66$ \\
8 & $80,78 \pm 2,93$ & $85,45 \pm 5,04$ & $84,45 \pm 4,16$ & $84,22 \pm 5,04$ \\
\hline Rataan & $85,63 \pm 2,81$ & $89,63 \pm 1,74$ & $88,34 \pm 4,76$ & $87,30 \pm 6,73$ \\
\hline
\end{tabular}

Hasil analisis ragam pada perlakuan menunjukkan tidak berbeda nyata $(P>0,05)$ terhadap produksi telur burung puyuh. Produksi telur burung puyuh pada R1 berkisar antara 83,14-92,57 \% dengan rataan $85,63 \pm 2,81 \%$, R2 berkisar antara 85,14$96,00 \%$ dengan rataan $89,63 \pm 1,74 \%$, R3 berkisar antara $84,45-93,71 \%$ dengan rataan $88,34 \pm 4,76 \%$, dan R4 berkisar antara 83,43 $95,43 \%$ dengan rataan $87,30 \pm 6,73 \%$. Hasil penelitian ini lebih tinggi dari pada penelitian lain yaitu burung puyuh yang diberi tepung daun jati (tectona grandis linn. f.) dalam ransum menghasilkan produksi telur burung puyuh berkisar antara 66,35 - 67,89\% [6]. Hasil penelitian yang tidak berbeda nyata disebabkan oleh pakan yang dipakai dalam perlakuan adalah sejenis sehingga memiliki kandungan nutrisi yang sama. Tinggi rendahnya telur yang diproduksi dipengaruhi oleh pakan [7]. Kandungan energi dan protein pakan berperan dalam produksi telur [8]. Selain itu umur dan jenis burung puyuh yang digunakan juga sama yaitu Coturnixcoturnix japonica sesuai dengan penelitian lain yang menjelaskan bahwa produksi telur dipengaruhi oleh genetik dan lingkungan seperti manajemen pemeliharaan dan nutrisi [9].

Berdasarkan hasil penelitian diketahui penggunaan larutan daun kelor dalam air minum dapat mempertahankan 
produksi telur burung puyuh. Hal ini disebabkan kandungan zat aktif seperti antioksidan, anti bakteri juga kandungan vitamin dan mineral yang terdapat didalam daun kelor dapat memperbaiki proses metabolisme dan pecernaan di dalam tubuh burung puyuh sehingga dapat mempertahankan produksi telur pada burung puyuh tersebut. Sesuai dengan penelitian yang lain yang membuktikan bahwa daun kelor (Moringa oleifera) mempunyai sifat anti bakteri dan anti jamur [10]. Bakteri patogen yang merugikan dalam saluran pencernaan burung puyuh dapat dibunuh oleh senyawa aktif yang terkandung dalam daun kelor, sehingga nutrisi yang terkandung dalam ransum dapat diserap dengan optimal oleh saluran pencernaan, kemudian secara nyata dapat meningkatkan efisiensi penggunaan ransum yang diberikan selama pemeliharaan untuk metabolis dan produktivitas telur. Pada daun kelor
(Moringa oleifera) telah diketahui mengandung bahan aktif sebagai antimikroba seperti flavonoid, saponin, tanin, dan senyawa fenolik lain yang mempunyai aktivitas antimikroba, bahan aktif antimikroba ini memiliki mekanisme dengan cara merusak membran sel bakteri dengan meningkatkan permeabilitas dari dinding sel bakteri [11].

\subsection{Bobot Telur Burung Puyuh}

Bobot telur merupakan akumulasi dari bobot kuning telur, bobot putih telur, dan bobot kerabang telur. Bobot telur dipengaruhi oleh unggas (genetik,umur saat dewasa kelamin, dan umur saat peneluran), pakan (kandungan protein, mineral, dan efisiensi terhadap pakan), dan lingkungan (cara pemeliharaan, cahaya, dan temperatur lingkungan) [12]. Rataan bobot telur burung puyuh selama penelitian disajikan padaTabel 2.

Tabel 2. Bobot telur burung puyuh (g/butir/minggu)

\begin{tabular}{ccccc}
\hline \multirow{2}{*}{ Minggu ke- } & \multicolumn{4}{c}{ Perlakuan } \\
\cline { 2 - 5 } & $\mathrm{R} 1$ & $\mathrm{R} 2$ & $\mathrm{R} 3$ & $\mathrm{R} 4$ \\
\hline 1 & $11,41 \pm 0,46$ & $11,26 \pm 0,46$ & $11,35 \pm 0,45$ & $11,67 \pm 0,24$ \\
2 & $11,41 \pm 0,40$ & $11,23 \pm 0,47$ & $11,40 \pm 0,45$ & $11,70 \pm 0,18$ \\
3 & $11,47 \pm 0,43$ & $11,27 \pm 0,43$ & $11,50 \pm 0,42$ & $11,62 \pm 0,17$ \\
4 & $11,15 \pm 0,26$ & $11,10 \pm 0,27$ & $11,35 \pm 0,36$ & $11,33 \pm 0,24$ \\
5 & $11,23 \pm 0,38$ & $11,27 \pm 0,31$ & $11,23 \pm 0,40$ & $11,34 \pm 0,25$ \\
6 & $11,11 \pm 0,36$ & $11,41 \pm 0,33$ & $11,16 \pm 0,40$ & $11,29 \pm 0,28$ \\
\hline
\end{tabular}




\begin{tabular}{ccccc}
\hline 7 & $11,05 \pm 0,21$ & $10,94 \pm 0,11$ & $11,16 \pm 0,37$ & $11,17 \pm 0,16$ \\
8 & $10,98 \pm 0,19$ & $10,95 \pm 0,16$ & $11,11 \pm 0,21$ & $11,25 \pm 0,34$ \\
\hline Rataan & $11,22 \pm 0,28$ & $11,16 \pm 0,25$ & $11,28 \pm 0,33$ & $11,42 \pm 0,14$ \\
\hline
\end{tabular}

Hasil analisis ragam pada perlakuan menunjukkan tidak berbeda nyata $(P>0,05)$ terhadap bobot telur burung puyuh. Bobot telur burung puyuh pada R1 berkisar antara 10,98 - 11,47g dengan rataan 11,22 $\pm 0,28 \mathrm{~g}$, R2 berkisar antara 10,95-11,41g dengan rataan 11,16g, R3 berkisar antara11,11 $11,50 \mathrm{~g}$ dengan rataan $11,28 \pm 0,33 \mathrm{~g}$, dan $\mathrm{R} 4$ berkisar antara 11,17 - 11,70 \% dengan rataan $11,42 \pm 0,14 \mathrm{~g}$. Hasil penelitian ini lebih tinggi dari hasil penelitian lain yaitu burung puyuh yang diberi suplemen omega-3 memiliki bobot telur antara 10,04 - 10,32 g dengan rataan 10,15 g [13. Hasil penelitian lain menemukan telur puyuh mempunyai bobot berkisar antara 7-11 gram butir [7]. Bobot telur dapat dipengaruhi oleh genetik yang diwariskan oleh induk [14]. Jenis puyuh juga tentu dapat mempengaruhi rataan bobot telur [15]. Selain itu faktor-faktor yang dapat mempengaruhi bobot telur yang dihasilkan diantaranya adalah jenis pakan, jumlah pakan, lingkungan kandang dan kualitas pakan [1].

\section{SIMPULAN}

Pemberian larutan daun kelor pada burung puyuh tidak berpengaruh nyata terhadap produksi dan bobot telur burung puyuh namun dapat mempertahankan produksi telur dan meningkatkan bobot telur burung puyuh. Pemberian larutan daun kelor $5 \%$ dapat meningkatkan produksi telur burung puyuh. Pemberian 15\% dapat meningkatkan bobot telur.

\section{DAFTAR PUSTAKA}

[1] Listiyowati, E. dan Roospitasari K. 2009. Puyuh Tata Laksana Budidaya Secara Komersial. Penebar Swadaya. Jakarta.

[2] Middleton, E.J., Kandaswami, C., danTheoharides, T.C. 2000. The effects of plant flavonoids on mammalian cells: implications for inflammation, heart disease, and cancer. Pharmacology Review 52: 673-751.

[3] Prihayanti. 2014. Potensi Tepung Daun Kelor (Moringa oleifera) sebagai Suplemen Beta Karoten untuk Menghasilkan Telur Puyuh yang Kaya Oksidan. IPB. Bogor.

[4] Sudrajat, D., D. Kardaya dan Sahroji. 2015. Produksi telur puyuh yang diberi air minum larutan daun sirih. Jurnal Peternakan Nusantara 1(2): 159 - 166. 
[5] Scott, M.L., C. Nesheim dan R.J. Young. 1982. Nutrition of The Chicken. 3rd Ed. Cornell University. M.L. Scott of Ithaca, New York.

[6] Shufia, E.T.A. 2014. Produktivitas Puyuh Petelur (Coturnix-coturnix japonica) yang Diberi Tepung Daun Jati (Tectonagrandis Linn. F.) Dalam Ransum. [Skripsi]. Departemen IImu Nutrisi Dan Teknologi Pakan. Fakultas Peternakan. Institut Pertanian Bogor.

[7] Anggorodi, R. 1995.IImu Makanan Ternak Unggas Kemajuan Mutakhir. Bogor. Fakultas Peternakan IPB.

[8] Brand, Z., Brand, T.S., dan Brown, C.R. 2003. The effect of dietary and protein levels on production in breeding female ostrich. Brit Poult Sci. 44(4):589-606.

[9] Akram., M.A.H. Shah., dan Khan M.I. 2000. Effect of varying floor space on productive performance of japanese quail breeders maintained under litter floor and cage housing systems. Pak. J. Agric. Sci. 37 (1-2).

[10] Sato, Y., Shibata, H., Arai, T., Yamamoto, A., Okimura, Y., Arakaki, N., dan Higuti, T. 2004. Variation in Synergistic Activity by Flavones and its Related Compounds on the Increased Susceptibility of Various Strains of Methicillin-Resistant
Staphylococcusaureus to $\beta$-lactam Antibiotics. Int. J. Antimicrob. Agents, 24(3): 226-233.

[11] Esimone, C.O., Irohal, R., Ibezim, E.C, Okeh, C.O, dan Okpana, E.M. 2006. In Vitro Evaluation of the Interaction between Tea Extracts and Penicillin G Against Staphylococcus aureus. Afr. J. Biotechnol. 5 (11): 1082-1086.

[12] Yuwanta, T. 2010. Telur dan Kualitas Telur. Gadjah Mada University Press, Yogyakarta.

[13] Bening I. 2011. Bobot, KomposisiFisik, dan Kualitas Interior Telur Puyuh (Coturnix-coturnix japonica) yang Diberi Suplemen Omega-3. (Skripsi). Departemen Ilmu Produksi Dan Teknologi Peternakan. Fakultas Peternakan. Institut Pertanian Bogor.

[14] Ensminger,M.A. dan Nesheim C. 1992. Poultry Science (Animal Agriculture Series). 3rd Edition. Interstate Publishers, Inc. Danville, Illinois.

[15] Santos, T.C., Murakami,A.E., Fanhani, J.C., dan Oliveira, C.A.L. 2011. Production And Reproduction of Egg and Meat Type Quails Reared in Different Group Sizes. Brazilian J.Poultry Sci. 13 (1): 9-14. 